\title{
EDWARD WYLLYS ANDREWS, IV, 1916-1971
}

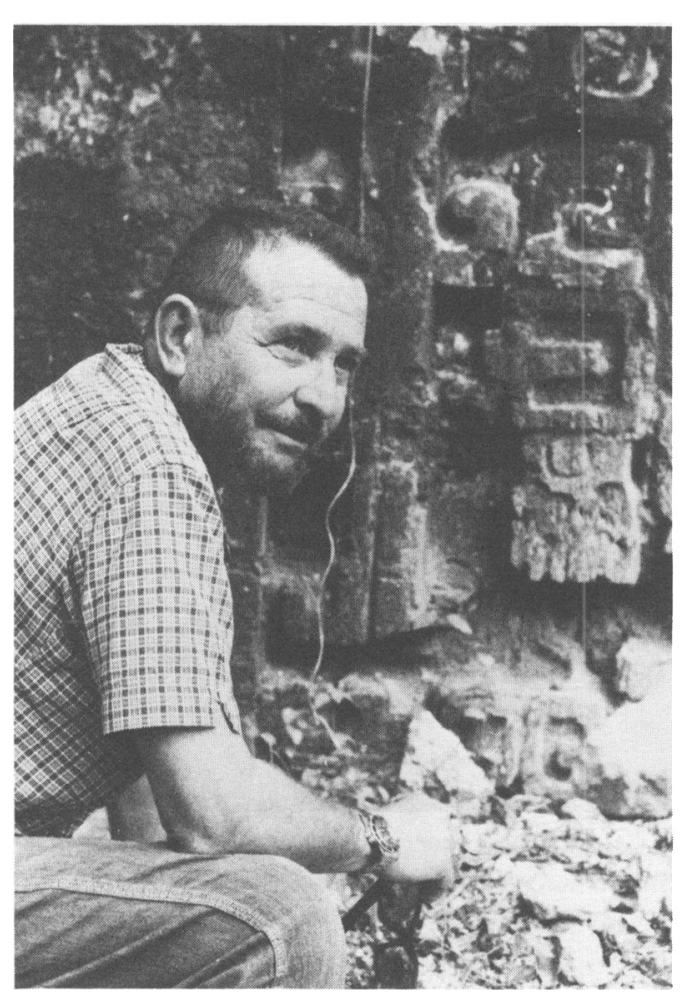

E. WYLLYS ANDREWS, IV, at Chicanna, Campeche, Mexico, in 1970. (Photograph by Richard H. Stewart, National Geographic Society.)
E. WYLLYS ANDREWS, IV, director of the program of research on the Yucatan Peninsula for the Middle American Research Institute of Tulane University, died in New Orleans July 3, 1971 , at the age of 54. Although best known as a Mayanist archaeologist and epigrapher, his interests and contributions to knowledge covered a wide spectrum: he published professional articles and monographs on herpetology and malacology and he enriched the archaeolog. ical programs which he administered with related studies in ethnology, linguistics, history, zoology, and ecology.

He was born in Chicago December 11, 1916, the son of Edmund Andrews and Irene Greene Dwen Andrews. Both Dr. Andrews, who was professor of surgery in the University of Chicago School of Medicine, and Mrs. Andrews had many intellectual interests. For example, they co-authored a comparative dictionary of Tahitian languages and Mrs. Andrews wrote several books, among them one on Tahiti and one on bookplates-her collection of over 150,000 bookplates was donated to Yale University. They encouraged such interests in their young son, giving him, at the age of 10 , a room in their home for his elaborate chemistry laboratory and his extensive collection of geological and paleontological specimens. By then Bill had already begun frequenting the Field Museum of Natural History to gain assistance in identifying his specimens. Like his father, he attended the Chicago Latin School, until 1929 when he accompanied his parents to Freiburg, Germany, and studied in German schools for $2 \mathrm{yr}$. Here he developed an interest in rare books, sixteenth and seventeenth century German etchings, and miniature portraits. Although his father was of the third generation of highly distinguished Andrews surgeons, he was also interested in history and archaeology, and he encouraged Bill's developing fascination with Maya antiquities.

Upon his return to the United States, Bill entered Lawrenceville, where he graduated in 1933. Here his early interest in the Maya as well as the natural sciences intensified; his trips to the Field Museum during vacations included visits with J. Eric S. Thompson and with Karl P. Schmidt, then assistant curator of amphibians and reptiles. Thompson told me recently that he was impressed at the time not only with Bill's wide reading and knowledge of the ancient Maya but also with such a young fellow's balanced and critical assessment of the Atlantis and Lost Tribes writings that were so popular at the time.

In 1932, through the intervention of E. A. Hooton, who was a family friend, Bill went on his first archaeological dig, a summer at Mesa Verde under Byron Cummings. At the end of the summer he traveled to Santa Fe to visit Sylvanus G. Morley for the first time. Arriving unannounced and claiming to be able to decipher Maya hieroglyphics, he was nevertheless welcomed by Morley, who was sufficiently impressed and kind enough to encourage Bill's youthful enthusiasm and promised to invite him to work at Chichen Itza following his senior year 
at Lawrenceville. At prep school, Bill devoted much if not most of his time to reading in Maya archaeology and collecting books on the subject, often to the neglect of his classroom studies, but in his senior year he did win the History Prize for the best history thesis-an exhaustive work on Hannibal's march through the Alps.

In 1933, following graduation at Lawrenceville, Bill enrolled for a fall term at the University of Chicago in order to take a course under Robert Redfield and to work at the Field Museum on Maya hieroglyphs and herpetology. At Morley's invitation, he went to Chichen Itza, Yucatan, in January, 1934, as Morley's assistant and to collect reptiles for Field Museum. Incidentally, it was here that I met Bill for the first time, and we took several long and adventurous trips together.

The following fall, Bill entered Harvard College. He graduated cum laude with a major in anthropology and immediately entered graduate school. During much of his early career, Bill was known as a "glyph man," for as a teenager at Lawrenceville he had become intrigued with Maya epigraphy. By 1934, at the age of 17 and before entering Harvard College, he had published in the American Anthropologist on Glyph X of the supplementary series of Maya inscriptions, and 4 of his first 5 articles, all published before he was 21 , were in this field.

The supplementary series, most of it now known as the lunar series, particularly interested Andrews. John E. Teeple had deciphered 3 of the glyphs in this groups, but the function and processes determining the various forms and coefficients of the others were still enigmatic. Andrews proposed a function for Glyph X and its usage and attempted to predict which of its 6 forms would appear for given moon-age dates and Glyph C forms. In a second article (1936), he presented notes and speculations on Glyph G; in another (1938a) he examined the relationship between 2 other signs, called $\mathrm{Y}$ and $\mathrm{Z}$, which are sometimes inserted in a Mayan text. He believed these last to be ritualistic rather than chronological. A fourth article (1938b) attacked Benjamin Lee Whorf's phonetic reading of Glyph C.

During his 1939-40 reconnaissance of southwestern Campeche, to be recorded below, Andrews had an opportunity to make a brief visit, his first, to Piedras Negras in El Peten, Guatemala. There he encountered a hieroglyphic text fragment which lay close to but not in direct association with fragments of Stela 38. Since he did not recognize the text, he photographed it and, after confirming that it had not been translated, published (1942a) his reading of the text, plus evidence that it was part of Stela 38. On the same expedition Andrews visited ruins near Moral, 1 day's journey up the Rio San Pedro Martir, where he found and recorded a stela with well-preserved Initial and supplementary series inscriptions carved in Peten style rather than that of the nearer sites of Yaxchilan, Piedras Negras, or Palenque.

For The Maya and Their Neighbors, a 1940 volume honoring A. M. Tozzer, Andrews was invited to write the chapter on chronology and astronomy in the Maya area, quite an honor for a graduate student not yet $23 \mathrm{yr}$ old. He reviewed the various correlations proposed for the Maya and European calendars, including a then-recent and largely overlooked one by Kreichgauer, and concluded that the 11.16.0.0.0. (Goodman-Martinez-Thompson) correlation was the best.

Although Andrews maintained an interest in epigraphy throughout his life, he could devote only a very small part of his research and writing to it after 1939, for his explorations and excavations drew him into the equally demanding fields of sculpture, architecture, and ceramics, plus the administrative chores of running long-term, well-staffed expeditions. In 1951, however, he published a valuable summary, in chart form, of all known Maya hieroglyphic texts containing Initial Series in association with lunar astronomical data, which had absorbed so much of his attention in earlier years. The tables provide readings of each inscription, qualifying notes, and bibliographic references. In 1958 he was invited to be a discussant of Thompson's lecture on "Research in Maya Hieroglyphic Writing" at a meeting of the American Anthropological Association in Boston. The same year he published, in our Tulane series, an article which gave revised readings of some dates on the hieroglyphic stairway at Copan, Honduras. He also occasionally wrote journal reviews of books in this field.

Until 1939, archaeological work in the Maya lowlands had been largely concentrated on northern Yucatan, the Peten and adjoining regions of Honduras, and British Honduras. The intervening country was known only through the architectural reconnaissance of the Puuc and Chenes areas to the north, by H. E. D. Pollock, and the explorations of Karl Ruppert, Miguel 
Angel Fernández, César Lizardi Ramos, and (much earlier) R. E. Merwin in southwestern Quintana Roo, southeastern Campeche, the Bacalar region, and the area immediately south of it. This left large unexplored lands south of Champoton and west of La Tuxpeña, Campeche, Tabasco north of the Usumacintla River, and northwestern Peten. In 1939-40, at the age of 22, Andrews undertook a reconnaissance of this unknown area for Carnegie Institution of Washington. Accompanied during much of the trip by Melvin A. Traylor, who collected birds for the Field Museum of Natural History, he went from Matamoros, Campeche, to a group of ruins reported near the chicle camp of Carrizal, then in a large circle to Pital, near the mouth of the Rio Mamantel at the Laguna de Terminos. The 2 then flew to Pacaitan on the Candelaria to explore this drainage system, traveling largely by boat. Andrews continued southward, crossing overland from San Enrique in the Candelaria to Tiradero on the Rio San Pedro Martir, and on to Tenosique, where he took advantage of the opportunity to journey upstream to Piedras Negras and Yaxchilan. At Tenosique, ruins were reported a day's journey upriver from the junction of the San Pedro Martir and the Usumacintla; Andrews visited this site, Moral, then proceeded by river to Carmen and returned by air to Pacaitan.

The trip, which lasted almost 3 months, resulted in Andrews' first major monograph (1943). It also furnished data for his Ph.D. dissertation at Harvard; the degree was awarded in 1942. The report, providing much new material, reflects Andrews' broad range of interests which characterized his entire professional career. One chapter, on physical environment, showed that historical geology has great archaeological significance in this region. Another chapter treated of the Spanish entradas, documentary research yielding ethnological data on the area. After presenting detailed site descriptions and an exhaustive analysis of comparative materials, Andrews discussed his conclusions as they bore upon the Maya-European calendar correlation problem. Writing at a time when anthropological functionalism was at the height of popularity and many scholars considered the correlation question, fascinating as it might be, relatively insignificant to anthropological thought, Andrews boldly declared it to be "probably the most important single problem in New World archaeology today ..." (1943:90), thus foreshadowing by many years the now widely acknowledged fact that until the correlation problem is solved, most matters of general anthropological interest in the Maya area-the rate of change in cultural processes to name only one-cannot be discussed except in vague terms.

Important as Andrews' Campeche data on earlier periods were, he maintained that the most significant remains he found were of later epochs, particularly the Mexican period (later, his "Modified Florescent"). On the basis of his observations at Las Ruinas and at Isla Cilvituk, relative to the already well-known sites of Chichen Itza and the East Coast, he postulated 3 phases of the Mexican period: (1) a stage represented by so-called "Toltec" Chichen Itza, corresponding to the Chichimec period in the north, A.D. 1200-1350;(2) a period represented by Mayapan, Tulum, and other East Coast sites, corresponding to the formative styles of Mixtec-Aztec culture in the north, A.D. 1350-1450; and (3) a final phase, corresponding to classical Mixtec-Axtec culture in continental Mexico, A.D. 1450-1525.

Andrews' examination of the Conquest period documents for Campeche persuaded him that Morley's routing of the Cortez and Avila entradas was erroneous, and that the cacicazgo of Acalan was probably centered on the Candelaria River rather than the upper San Pedro Martir. He believed that Mazatlan was either in the Isla Puc region or to the south in the direction of Tayasal. These conclusions were reached before Scholes and Roys' definitive work on Acalan was available. Andrews noted that sites like Las Ruinas offered "an invaluable opportunity ... for coordination of historical and archaeological research." As we shall see, this dual interest continued throughout his life, for some of the major sites he investigated (Xcaret, Dzibilchaltun) were occupied into conquest times.

Campeche again commanded Andrews' attention much later, but most of his fieldwork for the next several years, just before and after World War II, was devoted to northern Yucatan and Quintana Roo. In 1939 he published an article on a group of unusual sculptures at Telantunich, near Catmis, and showed that these were stylistically and conceptually related to stone figures at Kabah and Sayil, far to the northwest. Still another monument at Tabi provided a connecting link between this complex and the normal Maya sculpture. He considered these remains to be the 
expression of some religious cult, depicting the opposite of Maya canons of beauty, though whether they were later, earlier, or simply intrusive into Yucatan, he could not say.

In the winter of 1939-40, Andrews visited Tizimin, Yucatan, to examine the ruins of Hoopal, $28 \mathrm{~km}$ east of the city. The entire trip was made in a blinding rain, and because it was not possible to return with proper equipment, he published his sketch map and "what few rain-soaked notes" he was able to make, in the Carnegie Notes series. The site appeared to share traits common to the Mexican period at Chichen Itza and the East Coast area.

Just before the United States entered the war, in December, 1941, Andrews undertook, again for Carnegie Institution, an architectural study of 10 ruined sites within a radius of $40 \mathrm{~km}$ from Merida, until then an area curiously enough almost entirely unstudied by archaeologists. At 3 of these, George Brainerd made test excavations for pottery and analyzed the surface collections that Andrews took at the other sites. The most interesting of the season's finds was a group of ruins indicating widespread architectural activity in northern Yucatan during what was then called Old Empire times. They illustrated a style of temple architecture "rigid in itself and distinct from the elaborate patterns of later pre-Mexican construction on the northern part of the peninsula." The chronological separation of the early and late styles was attested "by actual superposition of buildings, the occurrence of transitional forms, and the association of distinct pottery types with the two architectural styles" (1942b:257). This reconnaissance, then, produced the basic outline of the archaeological sequence for northern Yucatan that Andrews was to define fully in later years, and explains why he was so anxious to continue work at Dzibilchaltun after the war.

On his return from Yucatan, Andrews volunteered for the United States Naval Reserve, was commissioned June 18, 1943, and took his naval indoctrination, with the rank of ensign, at Fort Schuyler, New York. He was assigned to the Office of Strategic Services, which was recruiting many anthropologists because of their knowledge of foreign countries and languages, their experience in organizing expeditions, working with people of different cultures, and obtaining and analyzing information. After further basic training at the OSS "farm" in Maryland and after serving for a period at the Spanish desk of OSS in Washington, he was sent to Casablanca in north Africa, later served in Italy and France, and toward the end of the war-now a lieutenant (j.g.)-was transferred to England for a mission into Germany. He was awarded the Legion of Merit for his achievements.

Andrews remained with OSS and its successor, the Central Intelligence Agency, for several years after the war. He bought a farm near Woodstock, Maryland, raised cattle there, and remodeled the historic residence on it, adding a wonderful stone-walled wing as a study and library. He apparently enjoyed sustaining for a number of years the excitement and fascination of secret intelligence operations; his work took him to the Middle East and Africa, and he was promoted to higher and higher responsibilities in CIA. Although offered positions involving missions in Latin America, he consistently declined them, for he had no intention of mixing intelligence operations with his professional career as an archaeologist.

The old yearning for archaeology grew stronger, and he finally made the break from Washington, moved to Merida in Yucatan, and was appointed Research Associate of the Middle American Research Institute of Tulane University. His interest turned chiefly to the East Coast, where, in 1955 , he investigated a number of major sites as guest of Loring M. Hewen of New York, who had regularly made trips along this coast and had discovered many ruins there.

Ever since 1941, Andrews had been intrigued with the potentialities of Dzibilchaltun in northwestern Yucatan, one of the sites he and Brainerd had investigated. Andrews' preliminary field work at Dzibilchaltun in 1956-57 partially documented the nature and extent of the Early period materials and uncovered a clear architectural-ceramic stratigraphy from these remains forward to Spanish colonial times. There were indications of a still earlier history extending back into the Formative past. Armed with this information, Andrews interested the National Geographic Society in his plans, and together he and I wrote proposals for grant support which we submitted to the National Science Foundation and the American Philosophical Society. All 3 institutions awarded funds for various aspects of the program, and work on a large scale, with a field staff of 7-many of them graduate students from various universities-aided by several Mexican scholars and technical specialists, plus a crew of 40-50 Indian laborers and 12 masons, began a project that was to 
continue, under permits issued by the Instituto Nacional de Antropologia e Historia, Mexico, for $10 \mathrm{yr}$.

There is insufficient space here to enumerate even the major results of the Dzibilchaltun program. Suffice it to say that Andrews established an uninterrupted prehistoric cultural sequence of some $3000 \mathrm{yr}$ for northern Yucatan, abundantly documented with architecture, ceramics, other artifacts, radiocarbon dates, burials, caches, stelae, and other remains. The program was expanded to include studies in colonial history, linguistics, zoology, malacology, and ethnology, to help interpret the archaeological records. A preliminary report on the project (Andrews 1960b) won the Lewis Prize for the best scientific report published that year in Proceedings of the American Philosophical Society. The Mexican government built a small museum at the site, which has become one of the leading tourist attractions in Yucatan.

Like those of many anthropologists who break new ground in their studies or who revise long-accepted interpretations, Andrews' opinions were often controversial. First, his belief that Dzibilchaltun was a truly urban center has been challenged by those who consider it merely another extensive archaeological zone, not a single city. Be that as it may, the 48 sheets of 1:2000 maps, showing structures packed side by side throughout the vast area, several hundred of them tested to determine the period or periods of their occupancy, make worthy of serious consideration Andrews' inferences regarding an urban economy and social organization for such a high population density.

Second, Andrews' new terminology for northern Yucatan periods rubbed many scholars the wrong way; they felt it was an unnecessary and confusing departure from standard Mesoamericanwide nomenclature. This new terminology was also influenced by a third Andrews opinion not yet accepted by most Mayanists: that the Pure Florescent Yucatan sites, such as those in the Puuc, postdated Tepeu 1-3 in the Peten. He hoped that his southern Campeche investigations would set tle this question one way or the other.

Fourth, his long transitional periods, inferred from very deep deposits with distinctive pottery, plus his many radiocarbon dates from Dzibilchaltun and other northern sites, strongly supported, he felt, a 12.9.0.0.0 (Spinden) correlation rather than the widely accepted 11.16.0.0.0 (GoodmanMartinez-Thompson) formula. A majority of archaeologists today are not ready to accept the former; I can only say that Andrews himself was, up to his death, loath to abandon the 11.16.0.0.0 correlation entirely; he had always favored it and he continued to speak of it as the one best supported by astronomical, historical, and (in many regions) archaeological evidence, but he felt obliged to point out that this correlation was in strong contradiction to his own carefully controlled data. He had the most important of his radiocarbon dates, including the twig samples from the Cave of Balankanche, re-run by other laboratories to check their accuracy.

Right or wrong, Andrews must be given credit for keeping our thinking on these matters stirred up and lively. It disturbed him to see existing concepts, terminology, and interpretations become unquestioned dogma. Both his conversation and his style of writing, however, often gave the impression that Andrews himself was positive and inflexible. Although he was aware and tolerant of conflicting data, he often seemed to ignore them when intent on driving home his own evidence and arguments. I think this was a result not only of Andrews' style but also of the almost unanimous opposition which he continually faced in seminars, book reviews of his progress reports, and discussions with his colleagues. He was perforce stubborn in these situations in order to get his opinions on the record rather than ignored. Here we should note, however, his standing policy that although he planned to write his own overall interpretations of the Yucatan and Campeche investigations, his staff members, in their individual reports, are free to express their own.

It was only natural that the National Geographic Society-Tulane University program of research in Yucatan should present many inviting opportunities to investigate new discoveries elsewhere than at the sites involved, for Andrews, living the year-around in Merida, was often called on by Mexican officials to supervise emergency situations. One of these was the discovery in 1959 , by José Humberto Gómez, a guide with Barbachano's Travel Service, of a sealed and hidden section of the long-known Grotto of Balankanche, near Chichen Itza. Opening the sealing masonry, Gómez found an extensive group of subterranean chambers rich with undisturbed archaeological remains. 
Under the overall direction of INAH Monumentos Prehispánicos, Andrews devoted 5 weeks of his program's efforts to explore and record the new caves and their contents, and prepare them as a museum accessible to the public. The sealed portions of the cave turned out to have been first entered in the tenth century and re-sealed not much more than a hundred years or so later, the dates confirmed by radiocarbon tests of carbonized twig samples contained in stone vessels. This was the Modified Florescent period when northwestern Yucatan was under the strong religious, artistic, and probably political influence of a Mexican Indian group popularly known as the Toltecs. "During this period," wrote Andrews (1961a:34), "this part of the cave was used for esoteric ritual concerning the rain god... not the Maya deity Chac but the Mexican highland cousin Tlaloc, and the material indicates the inclusion in the ritual of other highland deities in their pure native form."

Before mapping of the cave began, the local h-men asked to conduct a ceremony to propitiate the ancient gods before this sacred place was disturbed. Andrews readily agreed and obtained the Indian priest's permission to observe and record the ceremony with selected members of his staff. The final book on Balankanche (1970a) contained not only a full archaeological report and Maya transcription and Spanish translation of the ceremony (which lasted over 21 hours), but also a small phonograph recording of excerpts as they were taped.

Another side-product of the Yucatan program was Andrews' investigation of the Gruta de Chac, first explored by John L. Stephens in 1841. Before leaving northern Yucatan, I should mention Andrews' and George E. Stuart's work at Ikil, a recorded but undescribed site south of Libre Union in north-central Yucatan. They described, photographed, and prepared drawings, and also restored a single large pyramid, its surrounding platform mounds, and inscribed lintels; took ceramic samples; and recognized a superposition of architectural styles from the Early period through the Florescent, when, although dwarfed by Chichen Itza not far to the east, Ikil was possibly "an old shrine still considered sacred in these later times" (Andrews and Stuart 1968c:80).

Having outlined to his satisfaction the long prehistory of northern Yucatan, and realizing that its surprising data bearing on the correlation problem should be linked to those of the southern Maya lowlands, particularly the Peten of Guatemala, Andrews chose the intervening area of southern Campeche as his next theater of operations. The Rio Bec and Chenes areas were especially crucial in this plan, and he selected for his project the site of Becan and surrounding ruins, in a region only recently accessible by road and a small landing strip at Xpuhil, where he spent much of the first season building an expedition camp. The National Geographic Society again acted as co-sponsor with Tulane University in this project, which was planned for 3 field seasons, 1969-71. Supplemental funds for graduate student trainees in archaeology were received from the Ford Foundation.

It is still too soon to appraise the project's findings, with only Andrews' letters and periodic typewritten reports to INAH in hand at this writing, except to say that his Dzibilchaltun luck (or, more accurately, his predictions) held at Becan, too. The cultural sequence there reached from Formative times to the terminal prehistoric. Major excavations, repair, and reconstruction centered on Structure IV and on the unusual ditch surrounding the city, but architectural and ceramic studies were also made at Structures VIII, IX, and X, at Chicanna, Puerto Rico, and other spectacular ruins in the Rio Bec area.

Besides his site reports, which invariably fit his findings into broad concepts of Mesoamerican prehistory, a number of Andrews' writings treat exclusively of larger problems or constitute syntheses of the entire record of the Mayan past. He wrote the chapter on archaeology of the northern Maya lowlands for the Handbook of Middle American Indians (1965a). In July 1970 he delivered a paper, "The Emergence of Civilization in the Maya Lowlands," as a participant in a Wenner-Gren symposium at Burg Wartenstein, Austria (1970b). In 1970, he participated in and prepared a paper for a School of American Research seminar, in Santa Fe, New Mexico, on the development of Maya civilization after abandonment of the southern cities. With his friend, Stanley H. Boggs, he wrote an article showing that an African art object found in an apparently early archaeological context in El Salvador actually dated to the nineteenth or early twentieth century. It thus served as a warning to transoceanic diffusionists who draw unwarranted conclu- 
sions from supposedly well-documented Old World relics in the Americas (Andrews and Boggs 1967a). He recruited for his Yucatan and Campeche programs many experts in ethnology, linguistics, zoology, ecology, and other fields, to enrich the interpretation of the prehistoric data. He was intensely interested in malacology, published a monograph on the archaeological use and distribution of Mollusca in the Maya lowlands (Andrews 1969), and for many years prior to his death was preparing a definitive census of Caribbean shells, which will eventually be published by the Department of Geology at Tulane, under the editorship of his friends and colleagues, Harold and Emily Vokes, who were frequent visitors in Yucatan and helped with the identification of specimens.

His service with OSS and CIA was a separate career in wartime and postwar intelligence operations. He took up flying as a hobby after the war, obtained both private and commercial licenses for 2-motored aircraft, and owned a succession of airplanes from then on. In Yucatan, he regularly flew his own plane to the East Coast, Belize, Mexico City, San Salvador, Panama, Tikal in Guatemala, or any of the archaeological sites where there were adequate landing strips, including his expedition camp at Xpuhil. When he bought the Maryland farm near Washington, he took correspondence courses in cattle raising and developed his acreage from a deficit operation to a profit-making one. He also owned several farms in Illinois and kept abreast of agricultural theory, practice, and markets. He was an avid collector of Bromeliads and orchids; he frequently came back from flights to Guatemala and El Salvador loaded with little crates of plants for the spacious grounds of Quinta Mari, his Merida home named for the Middle American Research Institute.

Andrews never taught in a university -the idea did not appeal to him and he could afford to be selective in his jobs-but he frequently lectured to my classes and seminars on his visits to Tulane, and he conducted a course in Maya prehistory for students in a "Maya philology" class of the Universidad de Yucatán. After his death, the director of the class wrote a moving tribute in $E l$ Diario de Yucatan entitled "Adios, Mr. Andrews," in which he told of Bill's inspiring sessions in his library at Quinta Mari, where the refrigerator was a fringe benefit of the lectures.

Perhaps I am not the appropriate one to write of Andrews' personal characteristics, for we were close friends for over $37 \mathrm{yr}$. I do know that a few of the older crowd at Harvard, who were graduate students or instructors during his undergraduate years, considered him too brash a young prodigy, a bias that has endured in some cases ever since. All I can say is that I met Bill in Yucatan when he was 17, which should have been near the apex of any such behavior, and we hit it off fine, putting our initial friendship to the acid test of several long trips together, most of it by muleback, through the Puuc sites and down as far as Lake Chichankanab in Quintana Roo. We were friends at Harvard. For months during the war we shared an abandoned attic room in San Leucio, Italy. Later, at Tulane, there were times when we fought bitterly on administrative matters. It is difficult to imagine any friendship that could survive these long and varied relationships, but ours did. I found him not only brilliant, but charming, completely honest, devoted to his work and to his family, and holding the highest standards of professional behavior.

As for this last trait, Andrews expected the same dedication from his staff of field assistants, some of whom felt that he was far too hard a taskmaster. Bill was one of us old geezers who were graduate student field men in the days before high-paying fellowships, generous per diems, easy transportation, and comfortable camps; we all tend to look askance at the younger generation, or at least many of them. Bill had little or no patience with a well-paid assistant who was not grateful to work from 4:00 A.M. until late at night when this was necessary during the short field season. He was not asking any more of them than he had always exacted from himself. Several of Bill's field assistants considered him intellectually authoritative, intolerant of new concepts, and irritatingly stubborn. Yet, as I have mentioned, he gave them free hand to express any divergent opinions in their reports, and I have watched him wait patiently while some young sport delivered just to the 2 of us a formally phrased lecture, complete with pacing up and down, "indeeds" prefacing every other sentence, and other professorial idiosyncrasies. Throughout his life, Bill remembered the kind and understanding treatment he had received as a youth from Morley and Thompson, and he never failed to answer, in detail and with encouragement, the many letters he received from boys and girls requesting information about the Maya-often a very time-consuming task in his busy life. 
There are literally hundreds of Bill's friends, professional associates here, in Latin America, and abroad, and the many casual tourists who regularly imposed on his hospitality in Yucatan, who hold him in the highest regard, who remember his famous straight-up, freezer-chilled, 50-to-1 martinis (his particular version known as atómicas in Yucatan), his marvelous dinner parties, stimulating conversations, delightful wit, and profound knowledge. INAH officials in Mexico not only liked him but trusted him implicitly, which cannot be said of many gringos they have dealt with. Immediately following his death, they published long and moving tributes in the newspapers. His Maya Indian domestic staff adored him, and his relationships with his children were the finest I have had the privilege to observe. Besides Mrs. Andrews, the former Joann McManus, he is survived by E. Wyllys Andrews, 5th, and Anthony (children of Ann Wessels Andrews), Edmund and Robert (children of Rosemary Borst Andrews McLean), David and Margaret Dwen (children of Joann McManus Andrews), and one granddaughter.

Bill and Joann Andrews loved to take vacations on Borabora, a remote island near Tahiti. On their last trip there he was stricken with cancer of the pancreas; the jaundice and other symptoms, however, were diagnosed locally as hepatitis and he returned to Yucatan for several months to recover. It was not until an operation in New Orleans in January, 1971, that he learned what the future held. He returned to Yucatan hoping to finish some of his current writings, and he did complete an important manuscript on the social implications of masons' kits found at Dzibilchaltun and Muna, Yucatan. I visited him in Merida to go over the status of all the unpublished reports and to familiarize myself more closely with his local financial accounts. Throughout the visit and throughout 2 subsequent operations that kept him 2 months in a New Orleans hospital, Bill displayed a completely realistic and calm attitude toward his condition, but most of all concern for Joann, who was constantly at his bedside, for his friends, and the hospital attendants. He left his body to the Tulane School of Medicine, at the very last thinking not of himself but of others.

Knowing how much more he could have contributed if he had lived longer, we can take some reassurance in the knowledge that Andrews kept the most meticulous and always-current field notes, complete with drawings and photographs and almost in publishable form as they stand; we are also fortunate that Joann Andrews, besides administering his account balances along lines that she knows Bill would want, plans to keep the Merida laboratory and his extensive library open to those staff members who have research and reports on Dzibilchaltun and Becan yet to complete. We also know that Bill lived the kind of life he wanted-rich in adventure, productive in the studies he prized most, and devoted to his family and friends.

ROBERT WAUCHOPE

Department of Anthropology Tulane University

Bibliography of E. Wyllys Andrews, IV

Compiled by Robert Wauchope and Joann M. Andrews

1934 Glyph X of the supplementary series of the Maya inscriptions. American Anthropologist 36:345-354.

1936a Notes on Glyph G of the Maya inscriptions. Maya Research 3:306-308.

1936b (With Karl P. Schmidt) Notes on snakes from Yucatan. Field Museum of Natural History, Zoological Series 20:167-187.

1937 Notes on snakes from the Yucatan peninsula. Field Museum of Natural History, Zoological Series $20: 355-359$.

1938a Glyphs Z and Y of the Maya supplementary series. American Antiquity 4:30-35.

$1938 \mathrm{~b}$ The phonetic value of Glyph C of the Maya supplementary series. American Anthropologist 40:755-758.

1938c Some new material from Coba, Quintana Roo, Mexico. Ethnos 3:33-46.

1939 A group of related sculptures from Yucatan. Carnegie Institution of Washington, Contributions to American Anthropology and History 26.

1940a Chronology and astronomy in the Maya area. In The Maya and their neighbors, pp. 150-161. D. Appleton-Century Company, New York.

1940b Exploration in southwestern Campeche, Tabasco, and the Department of Petén. Carnegie Institution of Washington, Year Book 39:267-269.

1941a An ethnological note from Cilvituk, southern Campeche. Carnegie Institution of Washington, Notes on Middle American Archaeology and Ethnology 5. 
$1941 \mathrm{~b}$ The ruins of Culuba, northeastern Yucatan. Carnegie Institution of Washington, Notes on Middle American Archaeology and Ethnology 3.

1941c Pustunich, Campeche: some further related sculptures. In Los Mayas antiquos, pp. 125-135. E1 Colegio de Mexico, Mexico.

1942a The inscription on Stela 38, Piedras Negras, El Petén, Guatemala. American Antiquity 7:364-368.

1942b Yucatan: architecture. Carnegie Institution of Washington, Year Book 41:257-263.

1943 The archaeology of southwestern Campeche. Carnegie Institution of Washington, Contributions to American Anthropology and History 8.

1950 Review of Popol Vuh: the sacred book of the ancient Quiche Maya. English version by Delia Goetz and Sylvanus G. Morley. Scientific Monthly 71:281.

1951 The Maya supplementary series. In The civilizations of ancient America, Proceedings of the 29th International Congress of Americanists 1, edited by Sol Tax, pp. 123-141. University of Chicago Press, Chicago.

1956 We sought a lost city. The Times Picayune, Dixie Roto Magazine, June 24:2,8-9.

1958a Discussion of "Research in Maya hieroglyphic writing" by J. E. S. Thompson, Pan American Union, Social Science Monograph 5:58-60.

1958 b Light on the ancient Maya. Explorer's Journal 36:8-10.

1958c A revision of some dates on the hieroglyphic stairway, Copan, Honduras. Middle American Research Institute, Tulane University, Publication 26:1-8.

1959a Dzibilchaltun, la ciudad perdida de los Mayas. Excelsior, January 14-17.

1959b Dzibilchaltun, lost city of the Maya. National Geographic Magazine 115:90-109.

1959 c A lost Maya city arises. Explorer's Journal 37:11-17.

1959d Progress report on two seasons' work at Dzibilchaltun, northwestern Yucatan, Mexico: 1956-57, 1957-58. National Geographic Society, limited offset edition.

$1959 \mathrm{e}$ Review of Die Hieroglyphen der Maya-Handschriften, by Gunter Zimmermann. American Antiquity $24: 441-443$.

1960a Archaeological excavations in Yucatan. American Philosophical Society, Year Book 1959:466-467.

$1960 \mathrm{~b}$ Excavations at Dzibilchaltun, northwestern Yucatan, Mexico. Proceedings of the American Philosophical Society $104: 254-265$.

1960c Review of "Middle American anthropology: special symposium of the American Anthropological Association" by G. R. Willey, E. Z. Vogt, and Angel Palerm. American Journal of Archaeology 64:216-217.

1961a Excavations at the Gruta de Balankanche, 1959. Middle American Research Institute, Miscellaneous Series 11:28-40.

$1961 \mathrm{~b}$ Preliminary report on the 1959-60 field season, National Geographic Society-Tulane University Dzibilchaltun program. Middle American Research Institute, Miscellaneous Series 11:1-27.

$1961 \mathrm{c}$ Review of "Prehistoric ceramics and settlement patterns in Quintana Roo, Mexico" by W. T. Sanders. American Antiquity 27:123-124.

1962a Excavaciones en Dzibilchaltun, Yucatan, 1956-1962. Estudios de Cultura Maya 2:149-183.

1962b Excavations at Dzibilchaltun, Yucatan, 1956-1962. English translation of 1962a.

1963 (With Anna O. Shepard) Imitation jade ornaments from Dzibilchaltun, Yucatan. Carnegie Institution of Washington, Notes from a Ceramic Laboratory 3.

1964 Review of $A$ catalog of Maya hieroglyphics, by J. Eric S. Thompson. Archaeology 17:288.

1965a Archaeology and prehistory in the northern Maya lowlands: introduction. In Handbook of Middle American Indians, Vol. 2, edited by Gordon R. Willey, pp. 288-330. University of Texas Press, Austin.

1965b Explorations in the Gruta de Chac, Yucatan, Mexico. Middle American Research Institute, Tulane University Publication 31:1-21.

1965c Progress report on the 1960-1964 field seasons, National Geographic Society-Tulane University Dzibilchaltun program. Middle American Research Institute Tulane University, Publication 31:23-67.

1966 Review of Prehistoric Maya settlements in the Belize valley, by G. R. Willey, W. R. Bullard, Jr., J. B. Glass, J. C. Gifford, and others. American Anthropologist 68:1959-1960.

1967a (With Stanley H. Boggs) An African art object in apparently early archaeological context in El Salvador: a caveat to the diffusionist. Ethnos 32:18-25.

$1967 \mathrm{~b}$ Review of Early cultures and human ecology in south coastal Guatemala, by Michael D. Coe and Kent V. Flannery. Science 158:364-365.

1968a Dzibilchaltun, a northern Maya metropolis. Archaeology 21:36-47.

1968b National Geographic Society-Tulane University program of archaeological research at Dzibilchaltun, Yucatán, Mexico. National Geographic Society, Research Reports, 1963 Projects, pp. 241-242.

$1968 \mathrm{c}$ (With George E. Stuart) The ruins of Ikil, Yucatan, Mexico. Middle American Research Institute, Tulane University, Publication 31:69-80.

1968d Torre cilíndrica de las ruinas de Puerto Rico, Campeche. INAH Boletin 31:7-13.

1969a The archaeological use and distribution of Mollusca in the Maya lowlands. Middle American Research Institute, Tulane University, Publication 34.

1969b Review of Archaeological explorations in El Peten, Guatemala, by Ian Graham. American Antiquity 34:194.

1970a Balankanche, throne of the tiger priest. Middle American Research Institute, Tulane University, Publication 32. 
1970b The emergence of civilization in the Maya lowlands. Paper prepared in advance for participants in Burg Wartenstein symposium 47, Wenner-Gren Foundation for Anthropological Research. Mimeographed.

$1970 \mathrm{c}$ The development of Maya civilization after abandonment of the southern cities. Paper delivered at the School of American Research, Santa Fe, New Mexico, for a seminar on the collapse of Maya southern lowland civilization. (Xeroxed copy in the hands of Gordon R. Willey, Peabody Museum, Harvard University, to appear in a future publication.)

1971a The emergence of civilization in the Maya lowlands. In Observations on the emergence of civilization in Mesoamerica, edited by Robert F. Heizer and John A. Graham. Contributions of the University of California Archaeological Facility 11:85-96.

1971b Pre-agricultural or early ceramic remains on Yucatan coasts. American Philosophical Society, Year Book 1970 , pp. 540-541.

1971c Review of "La costa de Campeche en los tiempos prehispánicos: prospección cerámica y bosquejo histórico" by Alberto Ruz L. American Anthropologist 73:424-425.

n.d. (With Irwin Rovner) Archaeological evidence on social stratification and commerce in the northern Maya lowlands: Two masons' tool kits from Muna and Dzibilchaltun, Yucatan. Middle American Research Institute, Tulane University (in press, ms. 1971). 